\title{
Süreli Çocuk Yayınlarındaki Matematik Problemlerinin İncelenmesi
}

\author{
Şirin Okay ${ }^{1}$, Lütfi İncikabı ${ }^{2}$ \\ ${ }^{1}$ Milli Eğitim Bakanlı̆̆g, Kastamonu, Türkiye \\ ${ }^{2}$ Matematik ve Fen Bilimleri Eğitimi Bölümü, Eğitim Fakültesi, Kastamonu Üniversitesi, Kastamonu, Türkiye
}

Sorumlu Yazar: Lütfi İncikab1, lutfiincikabi@yahoo.com

Makale Türü: Araştırma Makalesi

Kaynak Gösterimi: Okay, Ş., \& İncikabı, L. (2019). Süreli çocuk yayınlarındaki matematik problemlerinin incelenmesi. Ĕ̈itimde Kuram ve Uygulama, 15(3), 186-203. doi: 10.17244/eku.536105

\section{Investigation of Mathematics Problems Placed in Children Periodicals}

\author{
Şirin Okay ${ }^{1}$, Lütfi İncikabı ${ }^{2}$ \\ ${ }^{1}$ Ministry of National Education, Kastamonu, Turkey \\ ${ }^{2}$ Department of Mathematics and Science Education, Faculty of Education, Kastamonu University, Kastamonu, Turkey
}

Corresponding Author: Lütfi İncikabı, lutfiincikabi@yahoo.com

Article Type: Research Article

To Cite This Article: Okay, Ş., \& İncikabı, L. (2019). Süreli çocuk yayınlarındaki matematik problemlerinin incelenmesi. Ĕgitimde Kuram ve Uygulama, 15(3), 186-203. doi: 10.17244/eku.536105 


\title{
Süreli Çocuk Yayınlarındaki Matematik Problemlerinin İncelenmesi
}

\author{
Şirin Okay ${ }^{1}$, Lütfi İncikab ${ }^{2}$ \\ ${ }^{1}$ Milli Ĕgitim Bakanlı̆̆l, Kastamonu, Türkiye \\ ORCID: http://orcid.org/0000-0001-5375-2941 \\ ${ }^{2}$ Matematik ve Fen Bilimleri Eğitimi Bölümü, Eğitim Fakültesi, Kastamonu Üniversitesi, Kastamonu, Türkiye \\ ORCID: http://orcid.org/0000-0002-7912-780X
}

\begin{abstract}
Özet
Bu çalışmanın amacı, geçmişten günümüze yayımlanan Bilim Çocuk ve TSE Öncü Çocuk dergilerinin matematik içeriklerini dergilerin fiziksel özellikleri, ilgili müfredatla uyumu ve yer verilen problemlerin karakteristikleri bağlamında analiz etmektir. Nitel doğaya sahip bu çalışmada problemlerin analizinde doküman analizi kullanılmışır. Araştırma kapsamında Bilim Çocuk Dergisi'nin 202 sayısı, TSE Öncü Çocuk Dergisi'nin 74 sayısı taranmış, matematiksel içerik tespit edilen sayfaları derlenmiştir. Araştırmanın bulgularına göre, dergilerde matematiksel içeriğe ayrılan alan toplam sayfaların \%4'üne karşıllk gelmektedir. Dergilerdeki matematiksel içeriğin yarıdan fazlasının (\%63) problem türü etkinliklerde olduğu, \%29'unun oyun olarak planlandığı ve sadece \%8 matematiksel makale şeklinde olduğu belirlenmiştir. Dergilerde kullanılan görsellerin çoğunluğunun (\%63) içeriğe uygun görseller olduğu fark edilmektedir. Dergilerdeki içerik incelendiğinde problem çözme becerilerinin yer verilen beceriler arasında ön plana çıktı̆̆ görülmektedir. Çocuk dergilerinde günlük yaşam problemlerine günlük yaşamla ilgili olmayan problemlere oranla daha az yer verildiği fark edilmiş̧ir. Ayrıca problem çözme yetisi, en fazla ihtiyaç duyulan gereklilik boyutu olarak göze çarpmıştır.
\end{abstract}

\section{Makale Bilgisi}

\author{
Anahtar Kelimeler: \\ Matematik eğitimi, problem \\ özellikleri, süreli çocuk \\ yayınları
}

Makale Geçmişi: Geliş: 06 Mart 2019

Düzeltme: 14 Mayıs 2019

Kabul: 14 Haziran 2019

Makale Türü: Araştırma Makalesi

\section{Investigation of Mathematics Problems Placed in Children's Periodicals}

\begin{abstract}
The aim of this study was to analyse the mathematical contents of Bilim Çocuk and TSE Öncü Çocuk periodicals in terms of the physical characteristics of the magazines, the compatibility with the curriculum and the characteristics of the problems. Being qualitative in nature, document analysis was used to analyse the problems in the children's periodicals. In the scope of the research, 202 issues of Bilim Çocuk, and 74 issues of TSE Öncü Çocuk were inspected and the mathematical content pages were compiled. According to the findings of the research, the mathematical content in the periodicals corresponded to $4 \%$ of the total pages. It was determined that more than half of the mathematical content in the magazines (63\%) was of the problem type, $29 \%$ was planned as play activities and only $8 \%$ was mathematical articles. It was noted that the majority of the images used in the magazines (63\%) are suitable for the content. When reviewing the contents of the periodicals, problem-solving skills seemed to come to the forefront of the skills involved. In addition, it was noticed that in children's magazines, the problems of daily life were given less emphasis than the problems not related to daily life. Moreover, problem solving abilities were found to be the most needed dimension.
\end{abstract}

\section{Article Info}

Keywords: Children periodicals, mathematics education, problem specifications

\section{Article History:}

Received: 06 March 2019

Revised: 14 May 2019

Accepted: 14 June 2019

Article Type: Research Article 


\section{Giriş}

Çevresiyle olumlu etkileşim içinde bulunan çocuğun eğitim ve öğrenimi hızlanır. Çocuk yayınları bu etkileşimin önemli öğelerinden biridir (Konar, 2004). Nitelikli dergi sayısının kısıtlı ve çocukların zamanlarını dolduran eylemlerin fazla olduğu ortamlarda onları okumaya yöneltmek ve karakter gelişimini desteklemek oldukça önemlidir (İdi Tulumcu, 2015). Yeterli ve dikkatli yayımcıların yönetimiyle çekici hale getirilip uygun fiyatlarla sunulan gazete ve dergiler günlük haber ve olayları nitelikli bir okuma materyaline dönüştürürler (Oğuzkan, 2000). Aynı zamanda çocuk dergileri çocuk için onunla aynı dili konuşan bir dost, bir arkadaş, bir sırdaş gibidir (Şirin, 2006). Buradan hareketle çocuğun kaliteli zaman geçirmesine vesile olan çocuk dergilerinin aynı zamanda onların okuma kültürlerine katk1 sağladığı söylenebilir. Okuma kültürü gelişen çocuk ise zaman içinde eleştirel ve çok yönlü düşünme becerisi kazanacak bu ise onun problem durumlarını yorumlamasına büyük ölçüde katkı sağlayacaktır. Bu yorumlama becerisi ise problem çözme becerisinin gelişiminde etkili olan temel faktörler arasındadır (İncikabı \& Tjoe, 2013).

Problem terimi özellikle öğrenciler tarafından sonucuna ulaşılması karmaşık hatta güç matematiksel bir süreç gibi algılansa da hayatın hemen her alanında bulunan bir olgudur. "Matematik eğitiminde 'problem' sözcügüne farklı anlamlar yüklenebilmektedir. Genel anlamıyla problemler, çözüm yolu önceden bilinmeyen ve çözümü aşikâr olmayan sorular olarak kabul edilmektedir.” (MEB, 2013, s. III). Kişi karşılaştığı bir problem durumunu anlamalı, doğru yorumlamalı, çözümler üretmeli, onları denemeli ve sonuçları gözlemlemelidir. Piaget'e göre çocukların bilişsel gelişimleri için problemlere ihtiyaçları vardır. Onların gelişimi adına önemli kabul edilen problem çözme deneyimlerinde ise problemlerin seçimi ve sunuş biçimi önem taşır. Özellikle seçilecek problemlerin gerçek yaşam problemlerini içeriyor olması çocuğun problem çözmeyi öğrenmesinde en önemli etkendir. (Aydoğan, 2012, s.9-10). Çocuğun gelişiminde yaşantı zenginliği ile oluşturulmaya çalışılan esasında farklı problem durumları ile karşılaşıp, çözümler üretebilme ve bunu zihinsel şemalarına ekleyebilmedir.

Süreli çocuk yayınlarının önemli içeriklerinden bir tanesi yer verdikleri düşünsel etkinliklerdir. Bunların başında da problem çözme etkinlikleri yer almaktadır. Problem çözme, öğretim programında yer alan her konu için geliştirilmesi istenen temel bir beceridir (MEB, 2013). Öğrencilerin üzerinde akıl yürütüp çözüm stratejileri üretebilecekleri, matematiksel bilgilerini kullanabilecekleri problem durumları bir öğrenme vasıtası olarak değerlendirilebilir. Problem çözme matematiğin ayrılmaz bir parçasıdır ve aynı zamanda matematik öğretiminin ana unsurları arasındadır (Pala, 2008). İlgili literatür incelendiğinde problem ve problem çözme üzerine birçok çalışma bulunmaktadır. Bu çalışmaların bir kısmı problem çözme becerileri üzerine (Birbiri, 2014; Çelik \& Güler, 2013; Gökkurt, Örnek, Hayat, \& Soylu, 2015; Özsoy, 2005) yazılırken, bir kısmı problem çözme stratejilerini (Altun \& Memnun, 2008; Durmaz \& Altun, 2014; Soylu \& Soylu, 2006; Yazgan, 2007) konu edinmişlerdir. Bazı araştırmacılar ise problem çözme süreçleri üzerine yoğunlaşmışlardır (Çalışkan, Selçuk, \& Erol, 2006; Soylu \& Soylu, 2005; Taşpınar Şener \& Bulut, 2015). Ayrıca problem incelemesi yapan çalışmalar da mevcuttur (Işsı, 2011; Işsk, Işsk, \& Kar, 2011; İncikabı \& Tjoe, 2013, Kar \& Işı1k, 2014).

Alan yazında çocuk dergileriyle ilgili yapılmış çalışmaların bir kısmı meşrutiyet dönemi ve cumhuriyetin ilk yıllarında yayınlanan dergileri incelemiştir (Balcı, 2003; Kıymaz, 2010; Sarıkaya, 2010; Ungan \& Yiğit, 2014). Bunların dışında çocuk dergilerindeki değerler eğitimini konu edinmiş çalışmalar (Gurbetoğlu, 2007; İdi Tulumcu, 2015) ve dergilerin yapısal özellikleri üzerine çalışılmış olanların (Demiryürek, 2009, 2012; Sürmeli, 2010) yanı sıra dergileri öğretim açısından değerlendirilenlere de (Kıymaz, 2015; Yıldız, 2012) rastlanılmıştır. Fakat güncel çocuk dergileri üzerine yapılmış çalışmaların yeterli olmadığı görülmektedir. Ayrıca öğretim konulu çalışmaların ağırlıklı olarak Türkçe öğretimi üzerine odaklandığ 1 fark edilmiştir. Çocuk dergilerinde matematiksel içeriğin araştırıldığı bir çalışmaya rastlanılmamıştır. Oysaki öğrenci ve öğretmenler için kaynak teşkil eden çocuk dergilerindeki matematiksel içeriğin araştırılması gereklidir. Yapılan çalışmanın bu bağlamda yapılan ilk çalışma olduğu düşünülmektedir.

\section{Araştırmanın Amacı}

Geçmişten günümüze yayımlanan Bilim Çocuk ve TSE Öncü Çocuk dergilerinin fiziksel özellikleri, ilgili müfredatla uyumu ve yer verilen problemlerin karakteristikleri bağlamında analiz etmektir.

\section{Araştırmanın Problemleri}

Yukarıda ifade edilen amaç doğrultusunda, bu araştırmada cevap verilecek sorular;

1. Çocuk dergilerinin boyutları ve matematiksel içeriğin kapladığı alan nasıldır? 
2. Dergilerde hangi matematiksel kavramlara, öğrenme alanlarına ve becerilere yer verilmiştir? $\mathrm{Bu}$ kavramların ilgili müfredattaki kapsamı nasıldır?

3. Dergilerde yer verilen problemler türleri ve özellikleri nelerdir?

4. Dergilerde yer verilen problemlerin gereklilik boyutları nası özellik göstermektedir?

\section{Yöntem}

$\mathrm{Bu}$ araştırma nitel bir araştırmadır. Süreli çocuk yayınlarındaki matematiksel içeriğin incelenmesi ve bu yayınlarda yer verilen problemlerin karakteristik özelliklerinin analiz edilmesi amaciyla doküman analizi yöntemi kullanılmıştır. Doküman analizi, araştırılmak istenen konu ile ilgili var olan kayıt ve belgeleri toplayıp belirli norm veya sisteme göre kodlayıp inceleme işlemidir (Cohen, Manion, \& Morrison, 1994; Çepni, 2012).

\section{Dergilerin Seçimi}

Teknoloji ve ekonomideki gelişmeler bilgiye erişimdeki çeşitliliği artırmıştır. Süreli çocuk yayınları bu çeşitliliğin bir parçasıdır. Bilgiye erişimi daha renkli ve daha eğlenceli kılan dergiler uygun kazanıma hizmet edecek ölçüde süzgeçlerden geçmelidir. Bu araştırmada Bilim Çocuk ve TSE Öncü Çocuk dergileri incelenmek üzere seçilmiştir. Dergilerin seçiminde hitap ettiği yaş grubu, derginin ulaşılabilirliği, pazar payları, resmi ve özel kurumlar ile olan ilişkisi göz önünde tutulmuştur. Dergilerin tamamına sosyal eğitim platformu Eğitim Bilişim Ağı (EBA) üzerinden ulaşılmıştır.

\section{Analiz Edilen İçeriğin Seçimi}

BÇ dergisinin ilk sayısından itibaren ve TSEÖÇ dergisinin 1998 Ocak sayısından itibaren 2014 yılı sonuna kadar olan sayılarına sosyal eğitim platformu Eğitim Bilişim Ağı (EBA) üzerinden ulaşılmıştır. Dergilerin her sayfası incelenmiş ve matematiksel içerik tespit edilmiştir. Elde edilen veriler matematiksel makale, matematiksel oyun ve problem olmak üzere üç alt başlıkta kategorize edilmiştir. Her bir içeriğe numara verilerek toplamda 1074 içeriğe ulaşılmıştır. (Tablo 1)

Tablo 1. Matematiksel İçerik

\begin{tabular}{lcccc}
\hline Dergi Adı & $\begin{array}{c}\text { Matematiksel } \\
\text { Makale }\end{array}$ & $\begin{array}{c}\text { Matematiksel } \\
\text { Oyun }\end{array}$ & Problem & $\begin{array}{c}\text { Genel } \\
\text { Toplam }\end{array}$ \\
\hline BÇ & $79(11)$ & $186(26)$ & $462(64)$ & 727 \\
TSE & $7(2)$ & $128(37)$ & $212(61)$ & 347 \\
Genel Toplam & $86(8)$ & $314(29)$ & $674(63)$ & 1074 \\
\hline
\end{tabular}

Not 1: Yüzdeler parantez içinde verilmiştir

\section{Analiz Kriterleri}

Tablo 2'de analiz kriterleri ve açıklamaları yer almaktadır. Problem analizinde dergilerin genel özellikleri, müfredat karşılaştırma, problem türleri ve problemlerin gereklilik boyutları incelenmiştir.

Dergilerin fiziksel özellikleri belirlenirken boyutları tespit edilmiştir. Dergilerin internet adresinden indirilen pdf formatlarındaki sayfa sayıları dergilerin boyutları olarak kabul edilmiştir. Dergilerde, matematiksel içeriğin tespiti için ise tüm dergiler sayfa sayfa incelenmiş, saptanan içeriğe tek tek numara verilmiştir. Sonrasında numaralandırılmış içerik için kapladığı alan bölümüne geçilmiştir. Aynı sayfadaki birden fazla içerik tek sayfa olarak kabul edilmiş, veri girişinde sadece ilk içerik için bir sayfa yazılmıştır. Eğer sayfada yalnızca bir içerik varsa sayfanın tamamını kapsamasına bakılmadan bir sayfa olarak kodlanmıştır. İçerik türü ise matematiksel makale, matematiksel oyun ve problem olarak üç kategoriye ayrılmıştır. Ayrıca bu araştırmada çocuk dergilerinde kullanılan görsellerin hangi nitelikleri taşıdıkları sorusunun cevabı aranmıştır. 
Tablo 2. Matematiksel İçerik Analiz Kriterleri

\begin{tabular}{|c|c|c|}
\hline Dergi Özellikler & $\begin{array}{l}\text { - Boyutlar } \\
\text { - Matematiksel içeriğin kapladığı alan } \\
\text { - İçerik türü } \\
\text { - Görseller }\end{array}$ & $\begin{array}{l}\text { - Dergilerin ulaşılan pdf formatlarındaki sayfa sayısı } \\
\text { - Numara verilmiş her bir içeriğin kapladı̆̆ı sayfa sayısı } \\
\text { - İçeriğin türü matematiksel makale, matematiksel oyun ve problem olarak ayrıştırılmıştır. } \\
\text { - Uygun ve uygun olmayan şeklinde iki alt başlıkta incelenmiştir. Görsel problem çözümünde direkt olarak } \\
\text { kullanılıyorsa uygun denilmiştir. Süsleyici olarak kullanılmış ise uygun değildir seçilmiştir. }\end{array}$ \\
\hline $\begin{array}{l}\text { Müfredat } \\
\text { Karşılaştırma }\end{array}$ & $\begin{array}{l}\text { - Matematiksel kavramlar } \\
\text { - Kavramların uygunluğu } \\
\text { - Beceriler } \\
\text { - Öğrenme alanı }\end{array}$ & $\begin{array}{l}\text { - İçerikte geçen matematiksel kavramlar sıralanmıştır. } \\
\text { - Kavram ilgili öğretim programında yer alıyorsa uygun, almıyorsa uygun değil kodlanmıştır. } \\
\text { - Akıl yürütme, araştırma sorgulama, bilgi teknolojilerini kullanma, iletişim, ilişkilendirme, işlemsel tahmin, } \\
\text { ölçmeye dayalı tahmin, problem çözme, psikomotor beceriler, yaratıcı düşünme, duyuşsal beceriler } \\
\text { - Cebir, geometri, olasılık ve istatistik, ölçme, sayılar }\end{array}$ \\
\hline $\begin{array}{l}\text { Problem türleri ve } \\
\text { özellikleri }\end{array}$ & $\begin{array}{l}\text { - Rutin ve Rutin olmayan (p. Kurma, bilmece, } \\
\text { proje, günlük) } \\
\text { - Açık ve kapalı uçlu } \\
\text { - Günlük yaşam (düzmece, veya gerçek) veya değil } \\
\text { - Yeterli bilgi; gereksiz bilgi; eksik bilgi } \\
\text { - Cevap tarzı (numerik cevap (NC), Cebirsel ifade } \\
\text { (CI),Tablo (T), Grafik (G), sözel (S), Açıklama } \\
\text { veya çözüm gerekli (AÇ) } \\
\text { - Problemin bağlamı: Sayısal ve sözel formda } \\
\text { verilmiş pür matematik durumları (PM), Resimli } \\
\text { gösterimler veya hikaye ile açılayıcı bağlam } \\
\text { (AB) }\end{array}$ & $\begin{array}{l}\text { - Ders ve sınıf ortamında kullanılan problemlere rutin, çok sık karşılaşılmayan, düşündürücü problemlere rutin } \\
\text { olmayan denilmiştir. } \\
\text { - Cevabı tek, kişiden kişiye değişmeyen problemlere kapalı uçlu, cevabı farklılık gösterebilen, birden fazla } \\
\text { cevabın doğru kabul edildiği problemlere açık uçlu denilmiştir. } \\
\text { - Düzmece veya gerçek olarak günlük yaşamı içine alabilen problemler günlük yaşam problemi olarak } \\
\text { isimlendirilmiştir. } \\
\text { - Problemde verilen bilgi durumu çözüm için yeterli ise yeterli bilgi, çözüme ulaşmak için başka bir bilgiye } \\
\text { ihtiyaç duyuluyorsa eksik bilgi, kullanılmayan bilgiler içeriyorsa gereksiz bilgi seçilmiştir. } \\
\text { - Probleme verilen cevabın tarzı altı kategoride düzenlenmiştir. } \\
\text { - Tamamen matematiksel bağlam ve Açıklayıcı bağlam olarak düzenlenmiştir. }\end{array}$ \\
\hline $\begin{array}{l}\text { Problem } \\
\text { gereklilik } \\
\text { boyutları }\end{array}$ & $\begin{array}{l}\text { - İşlemsel gereklilik: Tek adım (T), Çok adım (Ç) } \\
\text { - Bilişsel gereklilik: Tanımlama (T), İşlemsel } \\
\text { pratik (İP), Problem çözme (PÇ), Modelleme } \\
\text { (M), Matematiksel Muhakeme (MM) }\end{array}$ & $\begin{array}{l}\text { - Problem tek bir işlemle çözülebiliyorsa tek adım, birden fazla işlem gerekiyorsa çok adım denilmiştir. } \\
\text { - Problemin çözümüne ulaştıracak zihinsel gerekliliktir. }\end{array}$ \\
\hline
\end{tabular}


Dergi görselleri analizinde görseller uygun ve uygun olmayan şeklinde iki gruba ayrılmıştır (İncikabı, 2011a, 2011b). Problemlerde, görselde verilen bilgiler kullanılıyor, görsel olmadan sadece metin kısmıyla çözüme ulaşılamıyorsa uygun denilmiş̧ir. Çözüm için metin kısmının yeterli olduğu, görsellerin estetik amaçlı, süsleyici olarak kullanılması durumlarında ise uygun değil seçilmiştir.

Dergilerde hangi kavramlara ve becerilere yer verildiği ve bu kavramların ilgili müfredattaki kapsamının araştırılması için öncelikle her bir kavram yer aldığı derginin ait olduğu yılı kapsayan öğretim programı ile eşleştirilerek uygun veya uygun değil şeklinde sınıflandırılmıştır. Bu şekilde tespit edilen 1276 kavramın öğretim programı ile örtüştüğü, 45 kavramın ise ait oldukları öğretim programı içerisinde olmadığı fark edilmiştir. Müfredat karşılaştırma bölümünde ayrıca beceriler ve öğrenme alanları bulunmaktadır. İncelenen dergilerin ait oldukları yıllar itibari ile üç öğretim programı (1998-2005-2013 yıllarına ait) incelenmiştir. Böylelikle beceriler akıl yürütme, araştırma sorgulama, bilgi teknolojilerini kullanma, iletişim, ilişkilendirme, işlemsel tahmin, ölçmeye dayalı tahmin, problem çözme, psikomotor beceriler, yaratıcı düşünme olarak belirlenirken öğrenme alanları; cebir, geometri, olasılık ve istatistik, ölçme, sayılar olarak kategorize edilmiştir.

Araştırmamızda ayrıca problemlerin türleri incelenmiştir. Zhu ve Fan (2006), çalışmasında yer alan temalar temel alınarak problem türleri dört başlık altında incelenmiştir. Bunlar; rutin ve rutin olmayan, açik ve kapalı uçlu, günlük yaşam (düzmece veya gerçek) veya değil, yeterli-gereksiz-eksik bilgi şeklindedir. İncelenen problem, ders ve sınıf ortamında sıkça karşılaşılan, çözüm yoluna rahatlıkla ulaşılabilen, alışılagelmiş bir problem ise rutin problem olarak isimlendirilmiştir. Söz konusu problem sınıf ve ders ortamında sıklıkla kullanılmayan, çözüm yolu kişiler arası farkl11ık gösterebilen, fazladan düş ve düşünce gücü gerektiren bir problem ise rutin olmayan problem denilmiştir. Cevabı tek ve tartışmasız problemler kapalı uçlu, cevabı birden fazla olan problemler ise açık uçlu olarak yorumlanmıştır. Günlük yaşamın bir parçası veya bir kurgu ile günlük yaşamda karşılaşılabilecek bir temsil sunulmuş ise günlük yaşam problemi, günlük yaşamda karşılaşılamaz ise günlük yaşam olamayan problem olarak belirtilmiştir. Son olarak bu bölümde problemde verilen bilgi durumu incelenmiştir. Problemi oluşturan metin ve görselde verilen bilgi sonuca ulaşmak için kâfi ise yeterli bilgi, fazladan kullanılmayan bilgi içeriyorsa gereksiz bilgi, çözüme ulaşmak için verilen bilgi yeterli değil ise eksik bilgi şeklinde gruplandırılmıştır. İncelenen bir diğer alt başlık cevap tarzını irdelemiştir. Cevap tarzı problemin cevabını tasvir etmektedir. Cevabı sayılar oluşturuyorsa; Numerik Cevap, bilinmeyen ve sembol içeriyorsa; Cebirsel İfade, cevabı bir tablo içerisinde sunma zorunluluğu bulunuyorsa; Tablo, grafik şeklinde ifade gerektiriyorsa; Grafik, kelimelerle ifade edilebiliyorsa; Sözel, çözüm ya da gidiş yolunun açıklanmasını gerektiren durumlarda ise Açıklama veya Çözüm Gerekli alt kategorileri seçilmiştir. Problemin bağlamı ise Tamamen Matematiksel Bağlam ve Açıklayıcı Bağlam şeklinde kategorize edilmiştir (Harrison, 2001). Eğer problemin kökü sadece matematiksel ifadeler içeriyor ise Tamamen Matematiksel Bağlam, eğer kök baştan sona sadece yazılı kelimelerle oluşmuş ise Açıklayıcı Bağlam olarak kodlanmıştır (Zhu ve Fan, 2006).

Araştırmanın bir diğer amacı süreli çocuk dergilerinde yer alan problemlerin gereklilik boyutlarının hangi nitelikleri taşıdığının belirlenmesidir. Bu bölümde işlemsel gereklilik ve bilişsel gereklilik boyutları incelenmiştir. Zhu ve Fan (2006) problemlerde işlemsel gereklilik boyutunu tek basamaklı problemler ve çok basamaklı problemler olarak ikiye ayırmıştır. Bu çalışmada ise problem çözümü için gereken işlem bir tane ise tek adım, birden fazla işlem birlikte kullanılarak çözüme ulaşılıyorsa çok adım olarak verilere işlenmiştir. Bilişsel gereklilik boyutu ise; tanımlama, işlemsel pratik, problem çözme, modelleme, matematiksel muhakeme olarak sınıflandırılmıştır. Problemin çözüm aşamasında sahip olunması gerekli olan bilişsel işlev göz önünde bulundurulmuştur. Çözüme ulaşırken işlemler yeterli ise işlemsel pratik, problem çözme basamakları kullanılarak yorumlanıyorsa problem çözme, bir model yardımıyla çözüm ifade ediliyorsa modelleme, üst düzey matematiksel becerilerin gerekmesi durumunda ise matematiksel muhakeme kodlanmıştır (Harrison, 2001).

\section{Kodlama Süreçleri}

Kodlama süreci birbirinden bağımsız çalışan iki araştırmacı tarafından yürütülmüştür. Seçilen süreli çocuk yayınlarında tespit edilen 1074 içerik bu iki araştırmacı tarafından belirlenen kriterler doğrultusunda kodlanmıştır. Kodlayıcılardan bir tanesi bu çalışmanın araştırmacısı diğeri ise matematik eğitimi alanında uzman bir akademisyendir. Kodlanacak veriler üç ana gruba ayrılmıştır. Bu sürecin sonunda 86 matematiksel makale, 314 matematiksel oyun ve 674 problem, toplamda 1074 içerik tespit edilmiştir. Kodlanacak verilerin çokluğundan ötürü ilk olarak her bir gruptan aynı oranlarda olmasına dikkat edilerek 9 matematiksel makale, 31 matematiksel oyun ve 67 problem seçilerek her iki araştırmacı tarafından ayrı ayrı kodlanmıştır. Bu kodlamalar neticesinde araştırmacılar 
güvenirlik katsayısını Miles ve Huberman (1994) formülüne göre \%85,8 olarak hesaplanmıştır. Daha sonra araştırmacılar fikir birliğine ulaşmak için uyuşmazlık bulunan her bir maddeyi inceleyip ortak uzlaşı sağlamışlardır. Tekrar ayrı ayrı kodlama yapılmış, bu defa güvenirlik \%97 olarak hesaplanmıştır. Bu uyum yeterli bulunarak diğer kodlamalar yalnızca çalışmanın araştırmacısı tarafından yürütülmüştür.

\section{Örnek Kodlama}

Bu kısımda yukarda belirlenen kriterler doğrultusunda yapılan kodlamalara örnekler sunulmuştur. Fotoğraf 1' de bir matematiksel içerik örneği görülmektedir. Tablo 2'de verilen alt başlıklara göre kodlamalar gerçekleştirilmiştir. Derginin bu sayısı 64 sayfadan oluşmaktadır. Matematiksel içeriğin kapladığı alan ise bir sayfadır. İçeriğin türü problem olarak kodlanmıştır. Görseller kısmı görselde verilen bilgiler çözümde kullanıldığı için uygun seçilmiştir. İçerikte geçen sayı kavramı ilgili öğretim programında (MEB, 2013) ele alındığından uygun olarak kodlanmıştır. Öğrenme alanı sayılar ve işlemler olarak belirlenmiş, becerilerden problem çözme seçilmiştir. Problem türleri ve özellikleri belirlenmiştir. Verilen problem rutin ve kapalı uçlu bir problemdir. Günlük yaşamla ilişkilendirilmiştir ve verilen bilgiler problem çözümü için yeterlidir. Cevap tarzı nümerik cevap, problemin bağlamı ise tamamen matematiksel bağlam olarak kodlanmıştır. İşlemsel gereklilik çok adımlı işlem gerektirmektedir. Bilişsel gereklilik ise problem çözme olarak verilere işlenmiştir.

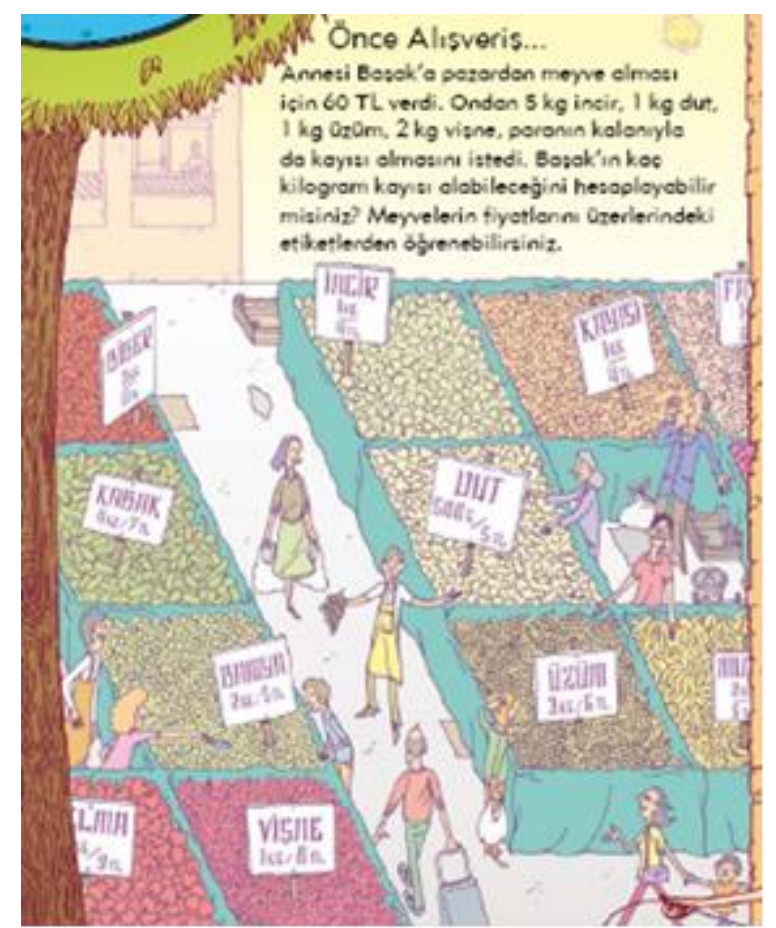

Fotoğraf 1. Örnek kodlama 1

Alıntılanan Kaynak: Bilim Çocuk, Eylül 2014, s. 57.

\section{Bulgular}

Her bir araştırma problemi dâhilinde çalışmada elde edilen bulgular bu kısımda ele alınmıştır.

Çocuk Dergilerinin Fiziksel Özellikleri

Tablo 3. Dergilerde Yer Verilen Matematiksel İçeriklerin Dağılımı

\begin{tabular}{lccc}
\hline & TSEÖÇ & BÇ & Toplam \\
\hline İçerik Sayısı & 347 & 727 & 1074 \\
Ayrılan Alan (sayfa) & $147(4)$ & $466(4)$ & $613(4)$
\end{tabular}

Not 1: Yüzdeler parantez içinde verilmiştir. 
Tablo 3' e bakıldığında TSEÖÇ ve BÇ dergilerinde toplamda 1074 adet matematiksel içerik belirlenmiş olup bu içerik için her iki dergide toplam 613 sayfa yer ayrılmıştır. Ayrılan alan dergilerde sayfa sayılarının \%4'üne tekâmül etmektedir. BÇ dergisinin matematiksel içerik sayısı ( $\mathrm{f}=727$ ) TSEOC dergisindeki içeriğin ( $\mathrm{f}=347)$ yaklaşık iki katıdır. Ancak ayrılan sayfa oranları her iki dergide (\%4) de aynıdır.

Tablo 4. Bilim Çocuk ve TSE Öncü Çocuk Dergilerindeki İçeriğin Türü

\begin{tabular}{lllll}
\hline & \multicolumn{3}{c}{ Etkinlik Türü } \\
\cline { 2 - 5 } Dergi Adı & Matematiksel makale & Matematiksel oyun & Problem & Genel Toplam \\
\hline BÇ & $79(11)$ & $186(26)$ & $462(64)$ & 727 \\
TSE & $7(2)$ & $128(37)$ & $212(61)$ & 347 \\
Genel Toplam & $86(8)$ & $314(29)$ & $674(63)$ & 1074
\end{tabular}

Not 1: Yüzdeler parantez içinde verilmiştir.

Tablo 4'te BÇ ve TSEÖÇ dergilerindeki bilimsel içeriğin türleri belirtilmiştir. İlgili tablo incelendiğinde dergilerdeki matematiksel içeriğin yarıdan fazlasının (\%63) problem türü etkinliklerde olduğu, \%29'unun oyun olarak planlandığ 1 ve sadece \%8'inin matematiksel makale şeklinde olduğu belirlenmiştir. Genel durumda belirlenen sıralama dergi özelinde de mevcut olmakla birlikte BÇ dergisinde matematiksel makalelere, TSEÖÇ dergisinde ise matematiksel oyunlara daha fazla yer verildiği saptanmıştır.

Dergilerdeki görsellerin uygunluğu Tablo 5'te analiz edilmiştir. Dergilerde kullanılan görsellerin çoğunluğunun (\%63) içeriğe uygun görseller olduğu fark edilmektedir. TSEÖÇ dergisinde kullanılan görsellerin uygunluk oranının (\%73), BÇ dergisindeki görsellerin uygunluk oranından (\%57) daha yüksek olduğu tespit edilmiştir.

Tablo 5. Dergilerdeki Görsellerin Uygunluğu

\begin{tabular}{cccc}
\hline & BÇ & TSE & Genel Toplam \\
\hline Uygun & $418(57)$ & $255(73)$ & $673(63)$ \\
Uygun Olmayan & $309(43)$ & $92(27)$ & $401(37)$ \\
\hline
\end{tabular}

Not 1: Yüzdeler parantez içinde verilmiştir.

BÇ dergisinin matematiksel içerik yüzdesinin yıllara göre dağılımı Grafik 1'de verilmiştir. Veriler incelendiğinde matematiksel içerik yüzdesi \%1 ile \% 8 arasında değişirken, bazı yıllarda içeriğin çok daha fazla alan kapladığı (2011) bazı yıllarda ise \%1’in altında kaldığı (2013) tespit edilmiştir.

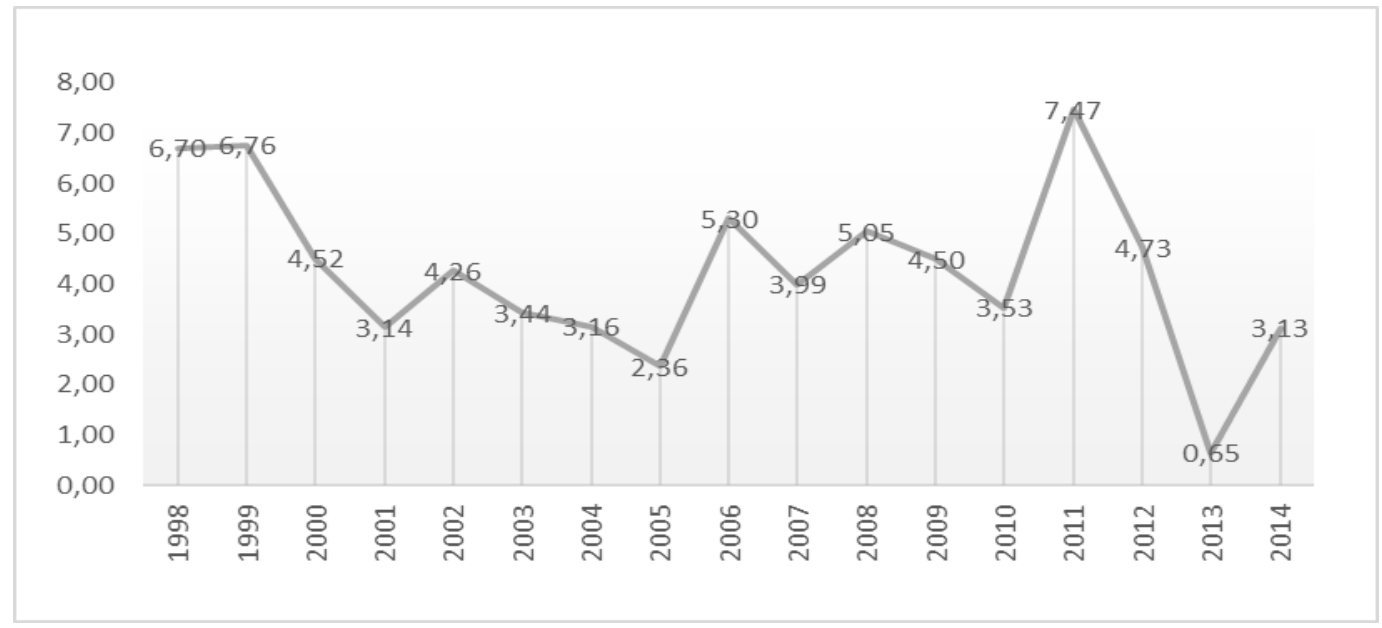

Grafik 1. Bilim Çocuk matematiksel içerik yüzdesinin yıllara göre değişimi

Grafik 2'de TSEÖÇ dergisinin içerik yüzdesinin yıllara göre değişimi gösterilmektedir. İçerik yüzdesinde artış ve azalışlar göze çarpmaktadır.1998 ile 2003 yılları arasındaki artış görülürken sonrasında 2009 yılına kadar içeriğin 
giderek azaldığı saptanmıştır. 2013 yılında matematiksel içeriğe daha fazla yer verilirken(\%8,17), 1998 ve 1999 yıllarında ayrılan alanın $(\% 0,79)$ diğer yıllardan çok daha az olduğu görülmektedir.

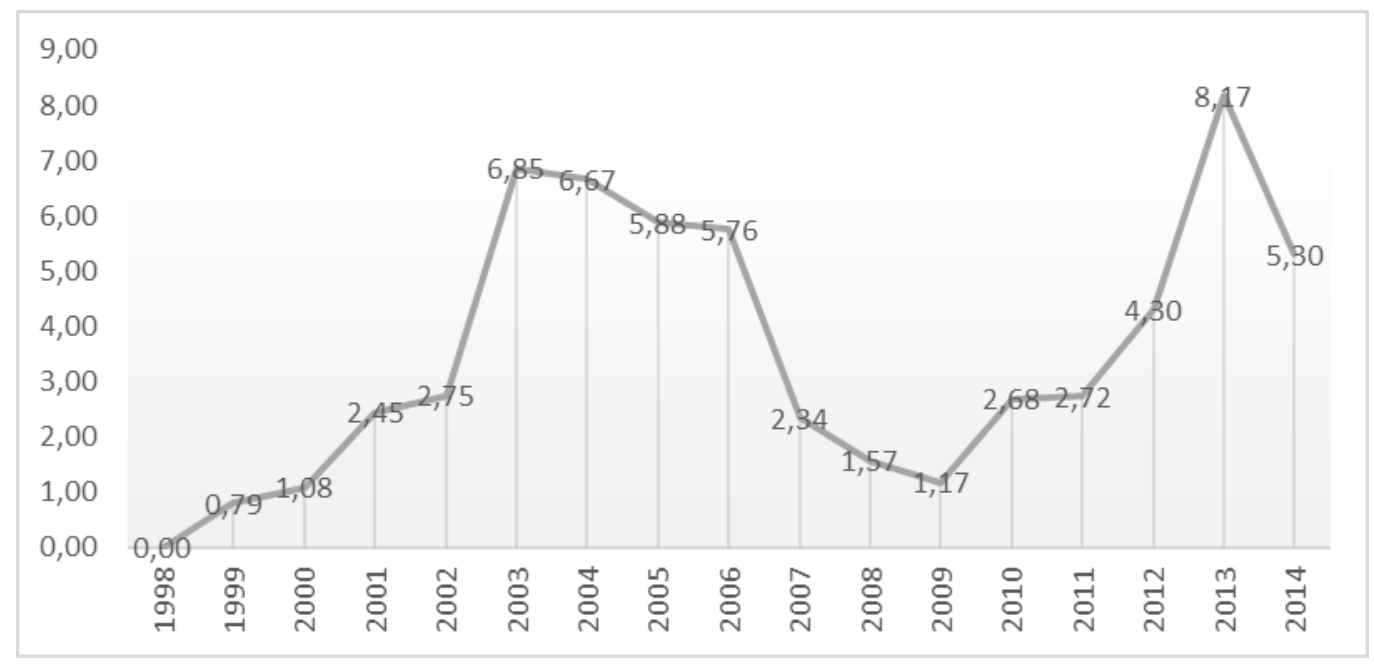

Grafik 2. TSE Öncü Çocuk matematiksel içerik yüzdesinin yıllara göre değişimi

BÇ ve TSEÖÇ dergilerindeki matematiksel içerik Grafik 3’te karşılaştırılmıştır. 2003 öncesinde BÇ dergisinde içerik yüzdesinin, 2003 ile 2006 yılları arasında ise TSEÖÇ dergisindeki içerik yüzdesinin daha fazla olduğu görülmektedir. İki dergi de benzer oranlarda matematiğe yer vermiş olmasına rağmen 1998, 1999 ve 2013 yıllarında söz konusu dergiler için içerik farkının dikkat çekici olduğu görülmektedir.

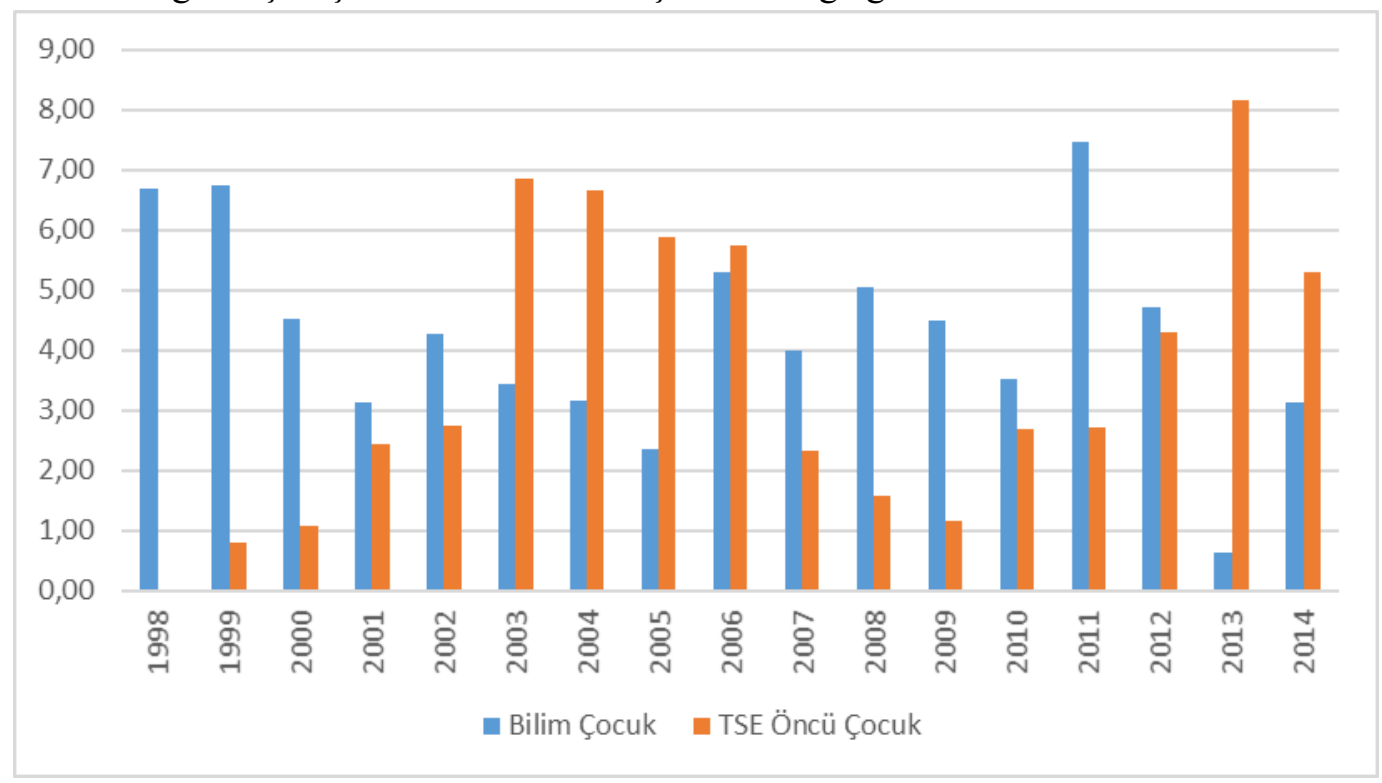

Grafik 3. Bilim Çocuk ve TSE Öncü Çocuk matematiksel içerik yüzdelerinin karşılaştırılması

\section{Dergilerde Yer Verilen Beceriler, Öğrenme Alanları ve Matematiksel Kavramlar}

Tablo 6'da BÇ ve TSEÖÇ dergilerinde yer verilen becerilere ait bulgular sunulmuştur. Genel içerik incelendiğinde problem çözme becerilerinin, yer verilen beceriler arasında ön plana çıktığ görülmektedir. Bu beceriyi tahmin stratejileri becerisi takip etmiştir. Akıl Yürütme, araştırma ve sorgulama ve ilişkilendirme becerilerine yakın oranlarda ( $f=66-73$ ) yer verilirken bilgi teknolojilerini kullanma, iletişim, duyuşsal beceriler ve yaratıcı düşünme becerilerine dergilerde oldukça az yer verildiği tespit edilmiştir. 
Tablo 6. Bilim Çocuk ve TSE Öncü Çocuk Dergilerinde Yer Verilen Becerilerin Dağılımı

\begin{tabular}{cc}
\hline Beceriler & Frekans \\
\hline Akı1 Yürütme & 74 \\
Araştırma Sorgulama & 66 \\
Bilgi Teknolojilerini Kullanma & 1 \\
Duyuşsal Beceriler & 1 \\
İletişim & 2 \\
İlişkilendirme & 73 \\
Problem Çözme & 589 \\
Psikomotor Beceriler & 28 \\
Tahmin Stratejileri & 239 \\
Yaratıcı Düşünme & 1 \\
\hline
\end{tabular}

Çocuk dergilerinde yer alan matematik içeriğinin öğrenme alanlarına göre dağılımı Tablo 7'de verilmiştir. İlgili dergilerde her program döneminde matematiksel içeriğin yarısından fazlası sayılar öğrenme alanına ayrılmıştır. Geometri içeriği dönemler bazında ve genel dağılımda (\%34-\%40 arası değişen) ikinci sırada yer almıştır. Diğer öğrenme alanlarına kıyasla ölçme ve olasılık-istatistik öğrenme alanlarına daha az yer verildiği fark edilmektedir. Hatta 2013 programı kapsamında incelenen dergilerin hiçbirinde ölçme öğrenme alanına ait içerik tespit edilememiştir.

Tablo 7. Bilim Çocuk ve TSE Öncü Çocuk Dergilerinin Program Yılları Kapsamında Öğrenme Alanları

\begin{tabular}{ccccc}
\hline & \multicolumn{4}{c}{ Program Dönemleri } \\
\hline Öğrrenme Alanları & $\mathbf{1 9 9 8 - 2 0 0 4}$ & $\mathbf{2 0 0 5 - 2 0 1 2}$ & $\mathbf{2 0 1 3 - 2 0 1 6}$ & Genel \\
\hline Cebir & $17(4)$ & $7(1)$ & $9(5)$ & $33(3)$ \\
Geometri & $138(34)$ & $195(40)$ & $70(40)$ & $403(38)$ \\
Olasıllk ve İstatistik & $31(7,5)$ & $24(5)$ & $1(1)$ & $56(5)$ \\
Ölçme & $1(\sim 0)$ & $4(1)$ & $0(0)$ & $5(\sim 0)$ \\
Sayılar & $221(54)$ & $260(53)$ & $96(55)$ & $577(54)$ \\
\hline
\end{tabular}

Not 1: Yüzdeler parantez içinde verilmiştir.

Not 2: işareti yaklaşık anlamına gelmektedir.

Tablo 8'de ilgili dergilerde geçen matematiksel kavramları ve bu kavramların derginin yayın yılında yürürlükte olan öğretim programı ile uyumu incelemektedir. Söz konusu dergilerde geçen matematiksel kavramlardan sadece 45 tanesi bağlı bulundukları yıldaki öğretim programı dışındadır (palindromik sayılar, sierpinski üçgeni, trepozoit, denkleştirme kuramı, kodlama... gibi). Bunun yanı sıra derginin çıkış yılına göre aynı kavram hem uygun hem de uygun olmayan kapsamında değerlendirilebilmektedir. Örneğin önden görünüm kavramı 2013 y1lı ve sonras1 için incelenen dergiler açısından program içerisinde yer almayan bir kavram sayılmıştır. Fakat daha önceki programlar kapsamında incelenen dergilerde ilgili yılların programında yer aldığından uygun olarak değerlendirilmiştir. Ayrıca söz konusu kavramların büyük çoğunluğunun sayılar ve işlemler ile geometri öğrenme alanları kapsamı içinde olduğu göze çarpmaktadır. 
Tablo 8. Çocuk Dergisi Matematiksel Kavramlar ve Müfredata Uygunluk

\begin{tabular}{|c|c|c|c|c|}
\hline $\begin{array}{c}\text { Öğrenme } \\
\text { Alanları }\end{array}$ & Uygun & f & Uygun Değil & f \\
\hline $\begin{array}{l}\text { Sayılar } \\
\text { ve } \\
\text { işlemler }\end{array}$ & $\begin{array}{l}\text { Ardışık sayılar, asal sayı, basamak, bölme, } \\
\text { bölünebilme, bütün, çift sayılar, doğal sayılar, dört } \\
\text { işlem, düzine, fark, işlem, fibonacci sayı dizisi, tam } \\
\text { kare sayılar, kesir, lira, matematiksel işlem, } \\
\text { matematiksel özellik, negatif sayılar, ondalık gösterim, } \\
\text { ondalık kesir, oran, örüntü, pi sayısı, pozitif sayılar, } \\
\text { rakam, sayı, sayı değeri, sayı grubu, sayı sistemleri, } \\
\text { sayının karesi, sıralama, tek sayılar, üçgensel sayılar, } \\
\text { yaş, yüzde }\end{array}$ & 535 & $\begin{array}{l}\text { Dizi, fibonacci sayı dizisi, } \\
\text { ikilik sayı sistemi, küpkök, } \\
\text { matris, milenium, mutlu } \\
\text { sayılar,örüntü, palindromik } \\
\text { sayılar, pascal üçgeni, } \\
\text { romen rakamları, sayı } \\
\text { dizilimi, sayı dizisi, sayı } \\
\text { matrisi, sayısal ilişki, } \\
\text { sierpinski üçgeni, sudoku, } \\
\text { yuvarlama }\end{array}$ & 30 \\
\hline Geometri & $\begin{array}{l}\text { Açı, alan, altıgen, benzerlik, beşgen, boyut, çap, } \\
\text { çember, çevre, çizgi, daire, daire dilimi, dar açı, } \\
\text { derece, dik açı, dikdörtgen, dikey, doğru parçası, } \\
\text { dönme, dörtgen, düşey, düzgün altıgen, düzlem, eğim, } \\
\text { eşkenar üçgen, fraktal, geometri, grafik, kare, kenar, } \\
\text { kesişim, kiriş, komşu kenar, koni, köşe, köşegen, küp, } \\
\text { küp açılımı, nokta, orta nokta, önden görünüm, } \\
\text { paralel, paralel kenar, piramit, Pisagor, prizma, satır, } \\
\text { sıra, silinidir, simetri, sütun, şekil, tablo, tangram, } \\
\text { teğet, tepe noktası, uzaklık, uzay, uzunluk, üçgen, } \\
\text { üstten görünüm, yamuk, yansıma, yarıçap, yatay, yön, } \\
\text { yükseklik, yüzey alanı }\end{array}$ & 585 & $\begin{array}{l}\text { Dairenin çeperi, elips, } \\
\text { gölge, izdüşüm, önden } \\
\text { görünüm, saat yönü, } \\
\text { sekizgen, tangram, } \\
\text { trepozoit, üstten görünüm, } \\
\text { yedigen }\end{array}$ & 11 \\
\hline Ölçme & $\begin{array}{l}\text { Ağırlık, birim, gram kilogram, kilometre, hacim, litre, } \\
\text { metre, metrekare, mililitre, milimetre, ölçme, ölçü, } \\
\text { saat, santimetre, takvim, zaman ölçme }\end{array}$ & 129 & & \\
\hline Olasılık & Olasılık & 13 & & \\
\hline \multirow[t]{2}{*}{ Cebir } & $\begin{array}{l}\text { Bilinmeyen, cebirsel ifade, denge, denklem, eşitlik, } \\
\text { formül, matematiksel eşitlik, sembol, simge }\end{array}$ & 16 & $\begin{array}{l}\text { Denkleştirme kuramı, } \\
\text { kodlama }\end{array}$ & 2 \\
\hline & Genel Toplam & 1276 & & 45 \\
\hline
\end{tabular}

\section{Dergilerde Yer Verilen Problemler Türleri ve Özellikleri}

Dergilerde yer verilen problemlerin özellikleri Tablo 9'da verilmiştir. Çocuk dergilerinde günlük yaşam problemlerine günlük yaşamla ilgili olmayan problemlere oranla daha az yer verildiği fark edilmiştir. Bu durum program dönemlerine göre analiz edildiğinde de benzer özellik sergilemiştir. Bunula birlikte günlük yaşam problemlerine yer verilme durumu 2005 yılı öğretim programı kapsamında incelenen dergilerde daha fazla (\%42) iken günlük yaşamla ilişkili olmayan problemler en fazla 2013 program döneminde yayımlanan dergilerde belirlenmiştir.

Tablo 9. Dergilerde yer verilen problemlerin türleri ve ilgili yıllara dağılımı

\begin{tabular}{ccccc}
\hline & $\mathbf{1 9 9 8}$ & $\mathbf{2 0 0 5}$ & $\mathbf{2 0 1 3}$ & Genel Toplam \\
\hline Günlük Yaşam & $93(38)$ & $120(42)$ & $47(34)$ & $260(39)$ \\
Günlük Yaşam Değil & $154(62)$ & $167(58)$ & $93(66)$ & $414(61)$ \\
\hline Rutin & $132(53)$ & $168(59)$ & $75(54)$ & $375(56)$ \\
Rutin Olmayan & $115(47)$ & $119(41)$ & $65(46)$ & $299(44)$ \\
\hline Açık Uçlu & $15(6)$ & $52(18)$ & $6(4)$ & $73(11)$ \\
Kapalı Uçlu & $232(94)$ & $235(82)$ & $134(96)$ & $601(89)$ \\
\hline
\end{tabular}

Not 1: Yüzdeler parantez içinde verilmiştir.

Tablo 9' a göre rutin ve rutin olmayan problemlerin çocuk dergilerindeki dağılım oranları birbirine yakın olmakla birlikte rutin problemlere dergilerde daha fazla yer verilmiştir. Rutin olmayan problemlere en fazla 1998 programı döneminde yayımlanan dergilerde yer verilirken rutin problemlere en fazla 2005 döneminde yer verilmiştir. 
Problemlerin açık veya kapalı uçlu olma durumları incelendiğinde dergilerde yer verilen problemlerin büyük çoğunlukla (\%89) kapalı uçlu sorular olduğu belirlenmiştir. Bu durum program dönemleri bazında da benzer özellik göstermiştir. Bununla birlikte 2005 yılı öğretim programını kapsayan yıllarda yayımlanan çocuk dergilerinde açık uçlu problem örnekleri diğer program yıllarına oranla biraz daha fazla (\%18) tercih edilmiştir.

Tablo 10'da incelenen dergilerde yer alan problemlerin özellikleri ele alınmıştır. Hem BÇ hem de TSEÖÇ dergilerinde problemlerin tamamına yakınının $(\% 98,3)$ yeterli bilgiye sahip oldukları görülmektedir. Toplamda yedi problem içeriğinde gereksiz bilgi saptanmış, beş problem içeriğinde ise eksik bilginin bulunduğu fark edilmiştir. İlgili dergilerde problem bağlamı analiz edildiğinde problemlerin çoğunluğunda (\%67) tamamen matematiksel bağlam hâkim iken problemlerin yaklaşık üçte birinde açıklayıcı bağlam tercih edilmiştir. İlgili dergilerin içeriğinde problemlere verilmesi gereken cevap tarzı incelendiğinde ise problemlerin yarısından fazlasının (\%52) nümerik cevap gerektiren problemler olduğu saptanmıştır. Bunula birlikte, problemlerde çözümün istendiği veya açıklama gereken durumlar \%29'luk oranla ikinci cevap tercihi olarak ele alınırken cebirsel ifade veya tablo oluşturularak cevap verilecek problem tarzlarının oldukça düşük oranlarda (sırasıyla \%2 ve \%3) yer aldığı belirlenmiştir.

Tablo 10. Problem Özellikleri

\begin{tabular}{cc|cc|cc}
\hline $\begin{array}{c}\text { Verilen bilgi } \\
\text { durumu }\end{array}$ & $\mathbf{f}(\boldsymbol{\%})$ & Problem Bağlamı & $\mathbf{f}(\boldsymbol{\%})$ & Cevap Tarzı & $\mathbf{f}(\boldsymbol{\%})$ \\
\hline Eksik Bilgi & $5(0,7)$ & Açılayıcı Bağlam & $222(33)$ & Açıklama veya Çözüm Gerekli & $195(29)$ \\
& & & Cebirsel İfade & $12(2)$ \\
Gereksiz Bilgi & $7(1)$ & Tamamen & \multirow{2}{*}{$452(67)$} & Nümerik Cevap & $353(52)$ \\
& & Matematiksel Bağlam & & Sözel & $94(14)$ \\
Yeterli Bilgi & $(98,3)$ & & & Tablo & $20(3)$ \\
\hline
\end{tabular}

Not 1: Yüzdeler parantez içinde verilmiştir.

\section{Dergilerde Yer Verilen Problemlerin Gereklilik Boyutları}

BÇ ve TSEÖÇ dergilerinde yer verilen matematiksel problemlerde işlemsel gereklilik boyutları Tablo 11'de verilmiştir. Dergilerde yer alan problemlerin büyük çoğunluğunda (\%84) çözüme çok adımlı işlemlerle ulaşılabilirken, yalnızca söz konusu problemlerin \%16'sında tek adımla cevaba erişilmektedir. Problemler bilişsel gereklilik açısından incelendiğinde, söz konusu problemlerin neredeyse yarısında (\%49) problem çözme yetisi, en fazla ihtiyaç duyulan gereklilik boyutu olarak göze çarpmıştır. Bunun yanı sıra işlemsel pratik, matematiksel muhakeme ve modelleme gereklilik boyutlarının birbirlerine yakın (\%11-\%19 arası değişen) değerlerde olduğu görülmektedir. İncelenen çocuk dergilerinde tanımlama gerekliliğine ise oldukça az (\%3) gerek duyulduğu görülmektedir.

Tablo 11. Problemlerin Gereklilik Boyutları

\begin{tabular}{cc|cc}
\hline İşlemsel Gereklilik & $\mathbf{f}(\boldsymbol{\%})$ & Bilişsel Gereklilik & $\mathbf{f}(\boldsymbol{\%})$ \\
\hline Çok Adım & $569(84)$ & İşlemsel Pratik & $122(18)$ \\
Tek Adım & $105(16)$ & Matematiksel Muhakeme & $129(19)$ \\
& & Modelleme & $77(11)$ \\
& & Problem Çözme & $327(49)$ \\
& & Tanımlama & $19(3)$ \\
\hline
\end{tabular}

Not 1: Yüzdeler parantez içinde verilmiştir.

\section{Sonuçlar ve Tartışma}

$\mathrm{Bu}$ araştırma, Bilim Çocuk ve TSE Öncü Çocuk dergilerinin boyutları ve matematiksel içeriğin kapladığı alanı araştırmayı, hangi kavram ve becerilere yer verildiğini ve bu kavramların ilgili öğretim programı ile uyumunu incelemeyi ayrıca kullanılan görseller, problem türleri ve problemlerin gereklilik boyutları bağlamlarında analiz etmeyi amaçlamıştır. Araştırma nitel bir araştırmadır ve doküman analizi yöntemi ile gerçekleştirilmiş̧ir. Bu çalışmadan elde edilen bulgular ilgili dergilerin 1998 ile 2014 yılları arasındaki sayıları ile sınırlandırılmıştır.

Araştırmanın bulguları her iki dergi için de matematiksel içeriğin kapladığı alanın sayfa sayılarının \%4'üne karşılık geldiğini göstermektedir. Süreli yayınlar genel anlamda bilim odaklı ve bilim odaklı olmayan içeriği farklı biçimler (makale, öykü, şiir, deney vb.) aracıllğıyla sunmaktadır. Bu durum okuyucunun aynı konuyu çeşitli 
perspektiflerden karşılaştırma imkânı sağlar (Seminoff, 1986). Bu durum ise bir konunun farklı bağlamlarda ele alınmasına neden olabilir. Bu özelliklere sahip olması beklenen çocuk dergilerinde matematiksel içeriğin az olması beklenen bir durumdur. Araştırma sonuçları ayrıca dergilerdeki matematiksel içeriğinin büyük çoğunluğunun matematiksel problemlerden oluştuğunu göstermektedir. Son \& Hu (2006), Çin ve ABD ders kitaplarının içerikleri karşılaştırmış, benzer bulgular elde etmişlerdir.

Yine araştırma bulgusuna göre dergilerde kullanılan görsellerin çoğunluğu uygun olan yani problemin çözümüne ya da kavramın anlaşılmasına katkı verecek görsellerden oluşmaktadır. Öğrenme kaynaklarında (dergi, kitap vb.) yer verilen görsellerin çocuklara ve öğrenmelerine uygun nitelikte olması önem taşımaktadır. Nitelikli görseller çocukların motivasyonunu artırmaktadır (Şimşek, 2001). Bunun yanında nitelikli görsellerin kullanımı, kaliteleri ve niceliği göz önüne alındığında, öğretmenler için öğrencilerin öğrenmelerini iyileştirebilecek yardımcı bir kaynak sağlar (Seminoff, 1986). Bu bağlamda Konar (2004), tezinde okul öncesi dönemde çocuk kitapları için kullanılan görsellerin metne uygunluğu ve tutarlılığını incelemiş kullanılan görsellerin büyük çoğunluğu tutarlı bulunmuştur. Yine İncikabi (2011a) ortaokul matematik ders kitaplarında kullanılan görsellerin önemli bir kısmının (yaklaşı \% 090 ) uygun görsellere yer verdiğini ortaya koymuştur.

BÇ ve TSEÖÇ dergilerinde becerilere ait bulgularda problem çözme becerisi ön plana çıkmaktadır. Problem çözme becerisi gerek ulusal ve uluslararası matematik dersi programlarında (MEB, 2017; NCTM, 2000) gerekse ilgili alan yazında yapılan çalışmalarda (örneğin, Polya, 2014; Schoenfeld, 2009) önemle vurgulanan beceriler arasındadır. Eğlendirici ve düşündürücü özelliklere sahip olması beklenen çocuk dergilerinin (Seminoff, 1986) bu amaç doğrultusunda problem içeriklerine daha fazla yer vermesi olağan bir durum olarak karşılanmalıdır.

Araştırma bulgularına göre dergilerde yer alan kavramların önemli bir çoğunluğu ilgili yıllardaki öğretim programı ile uyumludur. Dergilerin yayımlandığı dönemlerde müfredatlar da yer verilmeyen bazı matematiksel kavramların (örneğin fraktallar) sonraki dönemlerde yayımlanan matematik müfredatlarında yer alması dergilerin programlara etki edebilme potansiyelleri olduğu fikrine neden olabilir. Ayrıca kazanım dışı kavramlara çok az yer veriliyor olmasının dergilerin hedef kitlesiyle iletişimin sağlanması açısından olumlu olduğu söylenebilir.

Dergilerde günlük yaşamla ilintili problemlere az oranda yer verildiği saptanmıştır. Geçmişten günümüze matematik dersi öğretim programlarında yer verilen genel amaçlar arasında matematiği günlük hayatla ilişkilendirilmesi ve problem çözme çalışmalarında problemleri seçerken günlük hayatta yer alan senaryoların (durumların) seçilmesi yer almaktadır (MEB, 2005, 2013, 2017). Bu bağlamda dergilerin de bu amaca uygun içeriklere yer vermesi hedeflenen kitleye verilecek öğrenme desteği bakımından önemlidir. Ayrıca dergilerde matematiksel bağlama sahip, rutin, kapalı uçlu ve numerik cevap gerektiren problem yüzdesi daha fazladır. Benzer durum problem incelemesi yapan farklı çalışmalarda da karşılaşılmıştır (Hong \& Choi, 2014; Son \& Senk, 2010; Charalambous vd., 2010). Rutin problemlerin kullanılması öğrencilerin öğrendiklerini pekiştirmeleri bakımından önemli iken rutin olmaya çalışmalara yer verilmesi öğrencilerin bilişte yaşadığı dengesizlik (Piaget, 2002) durumlarıyla karşılaşmasına ve bu durumu aşarken var olan bilgi birikimini transfer etmesine olanak sağlamaktadır (Schoenfeld, 2009). Hong \& Choi (2014)'e göre numerik cevaplar gerektiren problemler yerine açılama gerektiren problemlerin seçilmesinin öğrencileri, matematik hakkında düşünmeye ve sebepleri irdelemeye teşvik edeceğini belirtmişlerdir. Açık uçlu problem çözme deneyimleri, sadece doğru cevabı bulmaya çalışmak yerine çözümlerin arkasındaki mantıksal düşünceye erişim sağlar; aynı zamanda eğitim açısından önemli bazı becerileri (örneğin anlamlı öğrenme) ve çoktan seçmeli sorularla etkin biçimde ölçülmesi çok karmaşık olan bilgi türlerini ölçmeye ve geliştirmeye olanak sağlar (Livingston 2009).

Dergilerde yer verilen problemlerin büyük çoğunluğunda (\%84) cevaba çok adımlı işlemlerle ulaşılabilmiştir. Matematiksel muhakeme gerektiren soru oranın ise düşük olduğu (\%19) görülmüştür. Benzer bulgulara öğrenme ortamlarının diğer unsurlarından olan ders kitaplarında (İncikabi, 2011a; İncikabı, Pektaş ve Süle, 2016; Ng, 2002; Pektaş, İncikabı, \& Yaz, 2015; Zhu \& Fan, 2006) ve uygulanan ulusal ve uluslararası sınavlarda da ulaşılmıştır (İncikabi, 2011a; İncikabi, Kurnaz, \& Pektaş, 2013). Bilişsel gereklilik boyutunda ise ilk sırayı problem çözme yetisi almıştır. Bu durum çocukların problem çözme ile ilgili belirli alışkanlıklar geliştirmesine ve TIMSS ve PISA gibi üst düzey düşünme becerilerin ölçüldügü ve farklı yapılarda problemlere yer verilen sınavlarda başarısızlık yaşamalarına neden olabilir. 
$\mathrm{Bu}$ çalışma çocuk dergilerin matematiksel içeriklerinin incelenmesi üzerine odaklanmıştır. Bu çalışmada elde edilen bulguların dergi yazarları veya editörleri, aileler ve öğretmenler açısından önemli olduğu düşünülmektedir. Dergi hazırlık sürecinde rol alan kurum ya da şahısların bu çalışmadan elde edilen bulguları dergilerin matematiksel içeriklerinin belirlenmesinde ve/veya sunumunda kullanabilirler. Yine bu araştırma, matematik eğitiminde veya diğer alanlarda uğraş gösteren araştırmacılar için bir zemin hazırlayabilir. Benzer mantıkla çocuk dergilerinin diğer içerikleri de analiz edilebilir. Öğretmenlerin çocuk dergilerine öğrenme ortamlarında yer vermelerine yönelik uygulamalara, öğrencilerin ve ailelerin dergileri belirlerken kullandıkları kriterlere odaklanacak nitel veya nicel araştırmaların bu çalışmanın sonucunu destekleyeceği düşünülmektedir. 


\section{Extended Summary}

Newspapers and magazines published for children are effective in filling the gap between textbooks and current events and newly discovered facts. Newspapers and magazines, which are made attractive by the board of publishers with sufficient care, are converted into qualified reading material by daily news and events (Oğuzkan, 2000). From this point of view, it can be said that children's magazines, which provide the child with quality material, also contribute to their reading culture. It can be said that children's periodicals fill the void that the textbooks cannot fill, entertain while training, and at the same time encourage reading, practice and learning in children.

Some of the important contents of children's periodicals are their intellectual activities. Among the contents, problem solving activities are at the core. Problem solving is a basic skill to be developed for each subject in the curriculum (MEB, 2005). Problem solving is an integral part of mathematics and is also one of the main elements of mathematics teaching (Pala, 2008). When the related literature is examined, there are many studies on problem and problem solving. Some of these studies focused on problem solving skills (One, 2014; Çelik \& Güler, 2013), while some of them investigated problem solving strategies (Soylu \& Soylu, 2006; Durmaz \& Altun, 2014; Arslan, 2002; Yazgan, 2007). Some researchers have also focused on problem solving processes (Taşpınar Şener \& Bulut, 2015).

The aim of this study was to analyze the mathematical contents of Bilim Çocuk and TSE Öncü Çocuk periodicals in terms of the physical characteristics of the magazines, the compatibility with the curriculum and the characteristics of the problems. Being qualitative in nature, document analysis was used to analyze the problems in the children's periodicals. In the scope of the research, 202 issues of Bilim Çocuk, 74 issues of TSE Öncü Çocuk were inspected and the mathematical content pages were compiled. The data to be encoded were divided into three main groups. At the end of this process, 86 mathematical articles, 314 mathematical games and 674 problems, 1074 content items in total, were determined.

According to the findings of the research, the mathematical content in the periodicals corresponded to $4 \%$ of the total pages. It was determined that more than half of the mathematical content in the magazines (63\%) was in problem type category, $29 \%$ was planned as play activities and only $8 \%$ was mathematical articles. It was noted that the majority of the images used in the magazines $(63 \%)$ were suitable for the content. When reviewing the contents of the periodicals, problem-solving skills seemed to have come to the forefront of the skills involved. In addition, more than half of the mathematical content was devoted to the area of numbers learning. Of the mathematical concepts mentioned in the magazines, only 45 (such as palindromic numbers, sierpinski triangle, trapezoid, equilibrium theory, coding) are out of the curriculum of the year they are affiliated to. Problem solving skills are among the skills highlighted in national and international mathematics courses (MEB, 2017; NCTM, 2000) and in studies in the related literature (eg, Polya, 2014; Schoenfeld, 2009). It is normal for children's journals (Seminoff, 1986), which are expected to have entertaining and thought-provoking characteristics, to give more space to the problem content for this purpose.

Among the general objectives included in mathematics teaching programs from past to present, mathematics should be associated with daily life and problem solving items selected by choosing daily scenarios (MEB, 2005, 2013, 2017). In this context, it is important for magazines to include content suitable for this purpose in terms of learning support to be given to the target audience. In addition, in the mathematical context of journals, the percentage of problem-solving which requires routine, closed-ended and numerical answers is higher. A similar situation has also been encountered in different studies investigating the problem (Hong \& Choi, 2014; Son \& Sync, 2010; Charalambous et al., 2010). The use of routine problems is important in terms of reinforcing what students have learned, while giving place to routine exercises enables students to encounter situations of imbalance (Piaget, 2002) in cognition and to transfer the existing knowledge when they face this situation (Schoenfeld, 2009). Hong and Choi (2014) stated that choosing problems that require explanation instead of problems requiring numerical answers would encourage students to think about mathematics and to examine reasons. Open-ended problem solving experiences provide access to the logical thinking behind solutions rather than just trying to find the right answer; it also allows for the measurement and improvement of the types of knowledge that are difficult to measure effectively and some educationally important skills (eg meaningful learning) with multiple choice questions (Livingston 2009). It has been noticed that in children's magazines, the problems of daily life are given less space than the problems not related to 
daily life. The distribution of routine and non-routine problems in children's periodicals is close to each other, and routine problems are given more space in the periodicals. When the cases of open and closed ended problems were examined, it was determined that most of the problems in the magazines were closed ended questions (89\%). It was seen that almost all of the problems $(98.3 \%)$ in both BÇ and TSEÖÇ journals have an adequate knowledge requirement for solving the problems. The majority of the problems (67\%) were in the form of a completely mathematical context, whilst an explanatory context was preferred for about one-third of the problems. When the answers that should be given to the problems were examined, it was determined that more than half of the problems (52\%) were problems requiring a numerical answer. In the vast majority (84\%) of the problems in the periodicals, the solution can be achieved with multi-step operations; single-step solutions are required by $16 \%$ of the problems. In addition, problem solving abilities are found to be the most needed dimension. 


\section{Kaynakça / References}

Altun, M., \& Memnun, D. S. (2008). Matematik öğretmeni adaylarının rutin olmayan matematiksel problemleri çözme becerileri ve bu konudaki düşünceleri. Eğitimde Kuram ve Uygulama, 4(2), 213-238.

Aydoğan, Y. (2012). Problem çözme ve problem çözme becerilerinin desteklenmesi. Ankara: Özgünkök.

Balcı, A. (2003). Bir okuma materyali olarak çocuk dergileri ve “çocuklara rehber”. Türklük Bilimi Araştırmaları, 13(13), 319.

Başaran Taş, E. (2008). Türkiye'de çocuk dergilerinin çocuk eğitimine katkısı ve milliyet kardeş dergisi (Yayımlanmamış yüksek lisans tezi). Marmara Üniversitesi Sosyal Bilimler Enstitüsü, İstanbul.

Birbiri, D. (2014). PISA 2003 ve PISA 2012 sınav sonuçlarının problem çözme becerilerine yönelik değişkenlerinin Türkiye açısından incelenmesi (Yayımlanmamış yüksek lisans tezi). Atatürk Üniversitesi Eğitim Bilimleri Enstitüsü, Erzurum.

Charalambous, C. Y., Delaney, S., Hsu, H. Y., \& Mesa, V. (2010). A comparative analysis of the addition and subtraction of fractions in textbooks from three countries. Mathematical Thinking and Learning, 12(2), 117-151.

Cohen, L., Manion, L., \& Morrison, K. (1994). Educational research methodology. Athens: Metaixmio.

Çalışkan, S., Selçuk, G. S., \& Erol, M. (2006). Fizik öğretmen adaylarının problem çözme davranışlarının değerlendirilmesi. Hacettepe Üniversitesi. Eğitim Fakültesi Dergisi, 30, 73-81.

Çelik, D., \& Güler, M. (2013). İlköğretim 6. sınıf öğrencilerinin gerçek yaşam problemlerini çözme becerilerinin incelenmesi. Dicle Üniversitesi Ziya Gökalp Ĕ̌itim Fakültesi Dergisi, 20, 180-195.

Çepni, S. (2012). Araştırma ve proje çalışmalarına giriş. Trabzon: Celepler Matbaa.

Demiryürek, G. (2009). Türkiye çocuk, diyanet çocuk ve ebe sobe dergilerinin yapısal özellikler bakımından değerlendirilmesi (Yayımlanmamış yüksek lisans tezi). Karadeniz Teknik Üniversitesi Sosyal Bilimler Enstitüsü, Trabzon.

Demiryürek, G. (2012). TRT çocuk dergisinin yapısal özellikler bakımından değerlendirilmesi. Kastamonu Üniversitesi Ĕ̆itim Dergisi, 20(3), 1017-1034.

Durmaz, B., \& Altun, M. (2014). Ortaokul öğrencilerinin problem çözme stratejilerini kullanma düzeyleri. Mehmet Akif Ersoy Üniversitesi Ĕ̈itim Fakültesi Dergisi, 30, 73-94.

Gökkurt, B., Örnek, T., Hayat, F., \& Soylu, Y. (2015). Öğrencilerin problem çözme ve problem kurma becerilerinin değerlendirilmesi. Bartın Üniversitesi Eğitim Fakültesi Dergisi, 4(2), 751-774.

Gurbetoğlu, A. (2007). II. Meşrutiyet dönemi çocuk dergilerinde ahlak eğitimi ve ahlaki değerler (1908-1918). Yüzüncü Yıl Üniversitesi Eğitim Fakültesi Dergisi, 4(1), 81-101.

Harrison, M. (2001). International Journal of Mathematical Education in Science and Technology.

Hong, D. S., \& Choi, K. M. (2014). A comparison of Korean and American secondary school textbooks: The case of quadratic equations. Educational Studies in Mathematics, 85(2), 241-263.

Işık, A., Işık, C., \& Kar, T. (2011). Matematik öğretmeni adaylarının sözel ve görsel temsillere yönelik kurdukları problemlerin analizi. Pamukkale Üniversitesi Ĕ̈itim Fakültesi Dergisi, 30(1), 40-49.

Işık, C. (2011). İlköğretim matematik öğretmeni adaylarının kesirlerde çarpma ve bölmeye yönelik kurdukları problemlerin kavramsal analizi. Hacettepe Üniversitesi Ë̆itim Fakültesi Dergisi, 41(41), 231-243.

İdi Tulumcu, F. (2015). Güncel çocuk dergilerinde yer alan değerler (Yayımlanmamış yüksek lisans tezi). Sakarya Üniversitesi Eğitim Bilimleri Enstitüsü. Sakarya.

İncikabi, L. (2011a). The coherence of the curriculum, textbooks and placement examinations in geometry education: How reform in Turkey brings balance to the classroom. Education as Change, 15(2), 239-255. 
Okay \& Incikabl

İncikab1, L. (2011b). After the educational reform: An analysis of geometry content in the Turkish mathematics textbooks. International Journal of Eurosia Social Sciences, 2(5), 38-54.

İncikabi, L., Kurnaz, M. A., \& Pektas, M. (2013). An investigation of mathematics and science questions in entrance examinations for secondary education institutions in Turkey. Journal of Baltic Science Education, 12(3), 352-364.

İncikabı, L., Pektaş, M., \& Süle, C. (2016). Ortaöğretime geçiş sınavlarındaki matematik ve fen sorularının PISA problem çözme çerçevesine göre incelenmesi. Journal of Kirsehir Education Faculty, 17(2), 649-662.

İncikabı, L., \& Tjoe, H. (2013). A comparative analysis of ratio and proportion problems in Turkish and the US middle school mathematics Textbooks. Journal of Kirsehir Education Faculty, 14(1), 1-15.

Kar, T. \& Işık, C. (2014). Ortaokul yedinci sınıf öğrencilerinin kesirlerle çıkarma işlemine kurdukları problemlerin analizi. Ilkögretim Online, 13(4), 1223-1239.

Kıymaz, M. S. (2010). Milli hafıza açısından kahramanlık hikayeleri: "İleri yavrutürk” dergisi örneği. Adıyaman Üniversitesi Sosyal Bilimler Enstitüsü Dergisi, 3(4), 103-117.

Kıymaz, M. S. (2015). Süreli çocuk yayınlarında edebi türler ve bu türlerin türkçe öğretimine katkıları (2011-2012) (Yayımlanmamış doktora tezi). Gazi Üniversitesi Eğitim Bilimleri Enstitüsü. Ankara.

Konar, E. (2004). 1995-2002 yılları arasında yayımlanan okul öncesi hikâye kitaplarındaki bazı kavramların içerik ve biçimsel olarak incelenmesi (Yayımlanmamış doktora tezi). Selçuk Üniversitesi Sosyal Bilimler Enstitüsü. Konya.

Livingston, S.A. (2009). Constructed-response test questions: Why we use them; How we score them. R. D. Connections 11,1-8.

Miles, M. B., \& Huberman, A. M. (1994). Qualitative data analysis: An expanded sourcebook. Sage.

Milli Eğitim Bakanlığı (MEB) (2005). İlköğretim matematik dersi (6, 7 ve 8. sinıflar) öğretim programı. Ankara.

Milli Eğitim Bakanlığı (MEB) (2009). İlkögrretim matematik dersi (1, 2, 3, 4 ve 5. sinıflar) ögretim programı. Ankara.

Milli Eğitim Bakanlığı (MEB) (2013). Ortaokul matematik dersi (5, 6, 7 ve 8. sınıflar) öğretim programı. Ankara.

Milli Eğitim Bakanlığı (MEB) (2017). Matematik dersi (1,2,3,4, 5, 6, 7 ve 8. sinıflar) ögretim programı. Ankara.

Ng, L. E. (2002). Representation of problem solving in Singaporean primary mathematics textbooks with respect to types, Polya's model and heuristics (Doctoral dissertation). Nanyang University National Institude of Education. Singapore.

Oğuzkan, F. (2000). Çocuk edebiyatı. Ankara: Anı Yayıncılık.

Özsoy, G. (2005). Problem çözme becerisi ile matematik başarısı arasındaki ilişki. Gazi Üniversitesi Ĕ̆itim Fakültesi Dergisi, 25(3), 179-190.

Pala, N. M. (2008). PISA 2003 sonuçlarına göre ögrenci ve sınıf özelliklerinin matematik okuryazarlı̆̆ına ve problem çözmeye etkisi (Yayımlanmamış yüksek lisans tezi). Balıkesir Üniversitesi Fen Bilimleri Enstitüsü. Balıkesir.

Pektaş, M., İncikabı, L., \& Yaz, Ö. (2015). Orta öğretim fen ders kitaplarının TIMSS çerçevesine göre analizi. Adıyaman University Journal of Educational Sciences, 5(1), 29-48.

Piaget, J. (2002). The language and thought of the child (5). Psychology Press.

Polya, G. (2014). How to solve it: A new aspect of mathematical method. Princeton university press.

Principles, N. C. T. M. (2000). Standards for school mathematics. Reston, VA: The National Council of Teachers of Mathematics.

Sarıkaya, M. (2010). Türk çocuk dergilerinde tarih 1918-1931. Cumhuriyet Tarihi Araştırmaları Dergisi, 6(12), 51-83.

Schoenfeld, A. H. (1992). Learning to think mathematically: Problem solving, metacognition, and sense making in mathematics. Handbook of research on mathematics teaching and learning, 334-370.

Seminoff, N. W. (1986). Children's periodicals throughout the world: An overlooked educational resource. The Reading Teacher, 39(9), 889-895. 
Son, J. W., \& Hu, Q. (2016). The initial treatment of the concept of function in the selected secondary school mathematics textbooks in the US and China. International Journal of Mathematical Education in Science and Technology, 47(4), 505530 .

Son, J. W., \& Senk, S. L. (2010). How reform curricula in the USA and Korea present multiplication and division of fractions. Educational Studies in Mathematics, 74(2), 117-142.

Soylu, Y., \& Soylu, C. (2005). İlköğretim beşinci sınıf öğrencilerinin kesirler konusundaki öğrenme güçlükleri: Kesirlerde sıralama, toplama, çıkarma, çarpma ve kesirlerle ilgili problemler. Erzincan Eğitim Fakültesi Dergisi, 7(2), $101-117$.

Soylu, Y., \& Soylu, C. (2006). Matematik derslerinde başarıya giden yolda problem çözmenin rolü. İnönü Üniversitesi Eğitim Fakültesi Dergisi, 7(11), 97-111.

Sürmeli, K. (2010). Türkiye'de eğitim amaçlı çocuk dergilerinde karşılaşılan temel grafik tasarım sorunları ve sorunlara çözüm önerileri (Yayımlanmamış doktora tezi). Ondokuz Mayıs Üniversitesi Sosyal Bilimler Enstitüsü, Samsun.

Şimşek, H. (2001). XIX. yüzyıl çocuk dergiciliği ve eğitsel işlevleri üzerine. Milli Ĕ̈itim Dergisi, (151), 1-9.

Şirin, M.R. (2006). Gösteri çă̆ı çocukları. İstanbul: İz Yayıncılık.

Taşpınar Şener, Z., \& Bulut, N. (2015). 8. sınıf öğrencilerinin matematik dersinde problem çözme sürecinde karşılaştıkları güçlükler. GEFAD, 35(3), 637-661.

Tüzel, S. (2013). Okul ile öğrenci yaşamı arasındaki duvarları yıkmak: popüler medyayı sınıfa taşımak. I. Çocuk ve Medya Kongresi, 13-39, İstanbul.

Ungan, S., \& Yiğit, F. (2014). Geçmişten Günümüze Türkiye'de süreli çocuk yayınları. Dil ve Edebiyat Eğitimi Dergisi, 10, 184198.

Yazgan, Y. (2007). Dördüncü ve beşinci sınıf öğrencilerinin rutin olmayan problem çözme stratejileriyle ilgili gözlemler. İlkögretim Online, 6(2), 249-263.

Yıldız, Z. (2012). Diyanet çocuk dergisinin din öğretimi açısından değerlendirilmesi. Süleyman Demirel Üniversitesi Sosyal Bilimler Enstitüsü Dergisi, 1(15), 367-390.

Zhu, Y., \& Fan, L. (2006). Focus on there presentation of problem types in intended curriculum: A comparison of selected mathematics textbooks from Mainland China and the United States. International Journal of Science and Mathematics Education, 4(4), 609-626. 